\title{
The timeliness of performance information in determining executive compensation
}

\author{
Kevin F. Hallock ${ }^{\mathrm{a}, *}$, Paul Oyer ${ }^{\mathrm{b}, 1}$ \\ a Department of Economics and Institute of Labor and Industrial Relations, University of Illinois, \\ 504 East Armory Avenue, Champaign, IL 61820, USA \\ ${ }^{\mathrm{b}}$ Kellogg Graduate School of Management and Institute for Policy Research, Northwestern University, \\ 2001 Sheridan Road, Evanston, IL, 60208 USA
}

Received 1 July 1997; accepted 1 February 1999

\begin{abstract}
We study whether boards of directors concentrate on performance near compensation decision times rather than providing consistent incentives for chief executive officers (CEO) throughout the fiscal year. We show empirically that managers can profit by moving sales revenue among fiscal quarters. Though this may suggest that boards use short-term trends when determining rewards, we find evidence consistent with boards tying pay to recent sales growth so as to use the best information about future performance. We also find that the timing of profits throughout the year does not affect CEO pay, which may suggest that smoothing firm income is important to CEOs. (C) 1999 Elsevier Science B.V. All rights reserved.
\end{abstract}

JEL classification: J41; J44; J33; M4

Keywords: Executive compensation; Performance timing; Managerial contracts; Boards of directors

\footnotetext{
* Corresponding author. Department of Economics and Institute of Labor and Industrial Relations, University of Illinois, 504 East Armory Avenue, Champaign, IL 61820, USA. Tel.: + 1-217-333-4842; fax: +1-217-244-9290; E-mail: hallock@uiuc.edu

${ }^{1}$ Tel.: +1-847-467-3790; fax +1-847-467-1777; E-mail: p-oyer@nwu.edu.
} 


\section{Introduction}

It has recently become well established that, in many professions, non-linear incentive contracts or performance measurement at discrete time intervals lead to variation in agents' marginal return to effort over the course of a year (see, for example, Healy, 1985; Leventis, 1997; Chevalier and Ellison, 1997; Oyer, 1998) People with "high-powered" incentives perform their jobs differently at different times of the year due to their reward structure. In this paper, we explore the actions of one set of agents who have been shown to have considerable incentives to manipulate the timing of their output - chief executive officers (CEOs) of large corporations. Because the budget and bonus cycles tend to revolve around firms' fiscal years, it seems plausible that compensation committees of boards of directors base compensation decisions on short-term trends. We test this notion empirically and establish that there is at least some evidence to suggest that short-term trends within a firm's fiscal year affect CEO compensation. We go on to consider whether boards might be acting rationally when using recent results because such results provide the best information available about future firm performance.

We address specific questions raised by the study of Oyer (1998) about the connection between sales revenue and compensation, as well as by the study of Healy (1985) on accounting earnings and compensation. Oyer (1998) showed that, holding calendar seasonality constant, firm sales tend to be higher at the end of the fiscal year, and lower at the beginning, than they are in the middle. He connected this fiscal seasonality to the often non-linear relationship between sales revenue and the compensation of salespeople and executives. One of our goals is to determine if executives have significant incentives to move sales from one fiscal quarter to another and to provide incentives for other agents in the organization to bunch sales in a manner similar to the patterns described in Oyer (1998).

We establish three inter-related empirical results. First, executives are rewarded more for fourth quarter sales growth than for growth earlier in the fiscal year. Second, in addition to being rewarded for current performance, CEOs are rewarded in year $t$ for year $t+1$ increases in earnings. Third, we show that fourth quarter sales growth is an excellent predictor of the following fiscal year's earnings growth and that, once fourth quarter sales growth is known, there is no additional explanatory power in the first three quarters' sales. These three facts suggest that, if the costs of CEOs' manipulating the timing of sales are not too great and if boards find it efficient to make most important compensation decisions annually, then a board that wants to use the most up-to-date projections about a CEO's performance may reward recent (that is, the last quarter) sales growth more than sales growth several quarters before.

We also build on the study by Healy (1985) of how upper and lower bounds on executive bonus packages encourage executives to make discretionary accounting accruals in a strategic manner. Healy (1985) found that executives with high 
marginal compensation from increased firm income take actions that increase their firm's income in the short term. However, executives at firms below their bonus plan's minimum income or above the maximum income attempt to defer their firm's income until such time as it provides them with more marginal compensation. Recent work has disputed Healy's finding that executives regularly take income-decreasing actions. Our empirical estimates show that, while executives undoubtedly take actions that are at least distracting in an attempt to maximize their bonuses, these actions are not a major determinant of overall compensation levels and do not appear to be excessively costly to firms. This suggests that either CEOs attempt to smooth their firms' incomes from year to year, that the earnings manipulation discussed by Healy (1985) is not an important determinant of total compensation, or that the income-increasing and income-decreasing actions of CEOs are roughly offsetting.

The rest of this paper proceeds as follows. Section 2 measures how manipulation of the timing of sales can affect executive pay and discusses why recent sales growth may be an effective instrument for determining optimal CEO pay. Section 3 builds on Healy (1985) by looking at how the timing of earnings affects executive compensation. We find that CEOs are paid strictly on the level of net income they produce, regardless of the timing of that income. Finally, Section 4 summarizes and discusses the implications of our work.

\section{The effect of the timing of sales growth on executive compensation}

Agents throughout many corporations, and especially executives and salespeople, are compensated with incentive contracts that feature a non-linear relationship between pay and revenue. Oyer (1998) showed that these contracts lead to a distinct pattern in firms' revenue. On average, manufacturing firms' sales (even after seasonal adjustment) are higher in the fourth fiscal quarter, and lower in the first fiscal quarter, than they are in the middle quarters. Many theories have been put forward as to why these non-linear incentive contracts are so prevalent, but none are completely satisfactory. ${ }^{2}$

In this section, we consider the possibility that these contracts are put in place by CEOs in order that they can then manipulate the timing of sales in a manner that will increase their compensation. We first find circumstantial evidence to support this idea because we show that executives can profit from manipulating the timing of sales. We go on to show, however, that manipulating sales timing cannot lead to large percentage changes in the average CEO's cash compensation.

\footnotetext{
${ }^{2}$ For example, Kim (1997) justifies quota/bonus plans through a principal agent model. Camerer et al. (1997) show that people may prefer to work towards targets, which suggests firms may be giving salespeople and executives their compensation plan of choice.
} 
We also find that, when making subjective compensation decisions, a compensation committee of a board of directors may have good reason to concentrate on sales growth in the very recent past, even if that provides incentive for CEOs to move sales from one fiscal quarter to another.

\subsection{Can executives profit by manipulating the timing of sales?}

CEOs can manipulate several items on a typical financial statement in an effort to make performance during a given fiscal period look good. In addition to the widely studied example of accounting accruals (see Section 3 for details on the prior literature), executives have considerable leeway to determine the exact timing of some sales. That is, near the end of fiscal periods, they can rush orders out to increase current period revenue or hold back shipments until the next fiscal quarter. ${ }^{3}$ They can also personally get involved in large orders to help insure that the business transacts quickly. In addition, since CEOs and other top executives determine the incentive contracts for salespeople and other employees, they can implement schemes that lead others in the firm to be especially productive during certain periods.

But how much can they profit from this manipulation of sales timing and how predictable or consistent is the best time of the year to make a sale? We answer these questions empirically in this section by measuring how the return to sales growth on CEO compensation varies over the course of firms' fiscal years. This requires a small, but intuitive, change to the standard method for measuring CEO pay-for-performance responsiveness.

Murphy (1985) and many subsequent studies (see Murphy, 1999) have estimated

$$
\Delta c_{i t}=\alpha+\delta \Delta s_{i t}+\eta_{i t}
$$

where $c_{i t}$ is the log of compensation for CEO $i$ in year $t, s_{i t}$ is the log of firm $i$ 's scale (for example, sales or market value) in year $t$, and $\eta_{i t}$ represents random factors. Other determinants of CEO pay, such as age, education, tenure, and firm fixed effects are either eliminated or absorbed into $\alpha$ when using change in pay as the dependent variable. Since the goal of the CEO is to increase the firm's scale, the change in scale, or $\Delta s$, can be thought of as "performance". ${ }^{4}$

\footnotetext{
${ }^{3}$ Under accrual accounting standards, revenue is recognized in the fiscal period during which a product is shipped to a customer. By moving a shipment from period $t$ to period $t-1$, for example, a company moves roughly the gross margin for the product from period $t$ 's pre-tax income to period $t-1$ 's pre-tax income.

${ }^{4}$ Differencing introduces serial correlation into Eq. (1). Also, the variance of changes in compensation is likely to differ substantially across firms and industries, causing heteroskedasticity in the error terms. Neither heteroskedasticity nor serial correlation cause bias in the estimation, but they may cause the OLS standard errors to be underestimated. To compensate for this, we use Huber standard errors and allow for within-company correlation in the OLS error terms.
} 
We examine sales as the relevant measure in this section. ${ }^{5}$ If other measures of firm performance are the true determinants of executive compensation, but, on the margin, executives cannot directly impact these measures, then executives can take actions to move sales from one quarter to another, hoping to impact the more important measures indirectly.

The critical difference between our analysis and that of Murphy (1985) is that we break up the performance variables into quarterly segments by updating Eq. (1) to

$$
\Delta c_{i t}=\alpha+\sum_{q=1}^{4} \delta_{q} \Delta s_{q i t}+\eta_{i t},
$$

where $s_{q i t}$ represents the $\log$ sales of firm $i$ in fiscal quarter $q$ of year $t$. The drawback of this approach is that when Eq. (2) is transformed from a log compensation equation to a levels compensation equation, it implies that CEO compensation is based on the geometric mean of the four quarters' sales, rather than the absolute sales for the year. That is, Eq. (2) implies that the CEO's pay is determined by the first quarter sales to the $\delta_{1}$ power times second quarter sales to the $\delta_{2}$ power and so on. This should not be a concern since we primarily focus on the relative magnitude of coefficients for each quarter, rather than being concerned with the point estimates themselves. Another problem with Eq. (2) is that the log of annual sales is not equal to the sum of the four log quarters' sales. If we define $\Delta s_{i t}$ as the difference in log annual sales, we cannot estimate Eq. (2), then estimate Eq. (1), and do an $F$-test on equality of the quarterly coefficients. Therefore, we define $\Delta s_{i t}$ as the sum of the four differences in log quarterly sales. We found that this does not materially affect the results of regressions that include annual sales, as we will discuss below. ${ }^{6}$

We employ two data sources. CEO compensation data are from the 1990-1996 Forbes Magazine's annual compensation issues. This survey, which covers firms' 1989-1995 fiscal years, includes data for CEO's from 800 of the largest firms in the United States each year. Though Forbes lists several measures of compensation, we focus on salary plus bonus, which averaged $\$ 1,037,000$ over our

\footnotetext{
${ }^{5}$ Sales are not meaningful in the banking industry, so banks and bank holding companies are dropped from any analysis that uses sales as a scale measure.

${ }^{6}$ An alternative specification, introduced by Jensen and Murphy (1990), has a more intuitive interpretation for our purposes. They studied differences in the level of CEO pay. They determined how much of any increase in the scale parameter goes to the CEO. This specification has the advantages of interpreting compensation as a function of the sum of quarterly scale parameters, rather than the product, that negative scale measures do not make the estimation more difficult (see Section 3 ), and that the four quarterly observations add to the annual value. However, our analysis with this approach proved problematic and did not fit the data as well as the log specification of Murphy (1985). Also, we found that our results were not qualitatively affected by the choice of log or linear specification.
} 
sample. ${ }^{7}$ The second data source is Standard and Poor's COMPUSTAT quarterly industrial file for the years 1987-1995. Data collected from COMPUSTAT includes information on the fiscal year and quarter, fiscal year end, sales (net), net income before extraordinary items, return on assets, and pretax income (see later sections). ${ }^{8}$ Appendix A contains summary statistics.

If executives cause the "unnatural seasonality" described by Oyer (1998) because fourth quarter sales weigh relatively heavily in the compensation decisions of the board of directors, then we should find that executive compensation is more responsive to firms' fourth fiscal quarter sales than other quarters' sales. Similarly, Oyer (1998) found that firms' have their lowest seasonally adjusted sales levels in the first fiscal quarter. If first quarter sales are lower because executives want to move sales to a quarter closer to the time compensation committees make decisions, compensation would be less affected by first quarter sales than by other quarters. We implicitly assume that most important decisions are made by the board at the end of the year.

Table 1 presents the results of our estimates of how sales timing affects CEO pay. The regression in column 1 indicates that for a typical firm, a $1 \%$ increase in sales volume leads to a $0.23 \%$ increase in CEO salary and bonus and that this result is highly statistically significant. ${ }^{9}$ The regressions in columns 2 and 3 allow sales increases in fiscal quarters to affect executive compensation individually. As reported in column 2, a 1\% sales increase in the fourth quarter increases executive compensation by $0.14 \%$ more than an increase in other quarters. This difference is statistically significant. According to the estimates in column 3, fourth quarter sales influence salary and bonus more than any other quarter, though the $F$-statistic indicates that we cannot reject the equality of the return to sales across fiscal quarters. ${ }^{10}$

\footnotetext{
${ }^{7}$ Forbes also reports "other" compensation (which includes such items as the value of savings contributions and memberships to clubs), as well as "total" compensation, which adds the value of options exercised. We found that our results are not dependent on our choice of compensation measure, so we use salary plus bonus because it best measures the effect of actions in a given year on short-term compensation.

${ }^{8}$ Note that quarterly accounting variables are generally only audited in the fourth fiscal quarter, so the potential exists for systematic differences in fourth quarter results. However, the companies in this dataset, because they are very large, work closely with their auditors throughout the year. Also, the effects of auditing are unlikely to be correlated with executive compensation.

${ }^{9}$ Note that the coefficient on the change in the log of sales, 0.0584 indicates that a $1 \%$ increase in sales in any single quarter leads to a $0.0584 \%$ increase in salary plus bonus. To see how an increase in annual sales affects annual CEO pay, we multiply this coefficient by 4 . When we use the change in log annual sales as an alternative explanatory variable, the coefficient is 0.2470 , with a $t$-statistic of 5.11 , which is very similar to the result implied by Table 1 .

${ }^{10}$ The results in Table 1 can come about without any manipulation whatsoever. The fourth quarter sales effect on pay indicates that there is at least some incentive to time sales if the board does not see through these efforts; not necessarily that the CEO can actually manipulate.
} 
Table 1

Response of CEO compensation to sales growth

Least squares regressions. The dependent variable is change in annual log (salary plus bonus) collected from Forbes. Sales data are collected from COMPUSTAT. The sample period is 1990-1996. Banks are not included because sales is not a relevant scale measure. Absolute value of $t$-statistics, which are based on Huber adjustments for heteroskedasticity and within-company serial correlation, are in parentheses.

\begin{tabular}{|c|c|c|c|}
\hline & (1) & (2) & (3) \\
\hline Change in log sales ${ }^{\mathrm{a}}$ & $0.0584^{* * *}(5.20)$ & $0.0259(1.35)$ & \\
\hline (Change in log sales) $\mathrm{q} 1$ & & & $-0.0144(0.19)$ \\
\hline (Change in log sales) $\mathrm{q} 2$ & & & $0.0721(0.91)$ \\
\hline (Change in log sales) $\mathrm{q} 3$ & & & $0.0211(0.30)$ \\
\hline (Change in log sales)q4 & & $0.1412 * *(2.01)$ & $0.1626^{* * *}(2.90)$ \\
\hline Constant & $0.0371 * * *(8.15)$ & $0.0365 * * *(7.95)$ & $0.0366^{* * *}(8.01)$ \\
\hline$R^{2}$ & 0.0158 & 0.0182 & 0.0184 \\
\hline$P$-value on restrictions ${ }^{\mathrm{b}}$ & & & 0.235 \\
\hline$N$ & 2590 & 2590 & 2590 \\
\hline
\end{tabular}

${ }^{\text {a }}$ Defined as the sum of the four quarters' change in log sales.

${ }^{\mathrm{b}} P$-value is from an $F$-test of the null hypothesis that the effect of sales is the same across fiscal quarters.

* Significant at $10 \%$ level.

** Significant at $5 \%$ level.

*** Significant at $1 \%$ level.

While there is evidence that sales growth in the fourth fiscal quarter has a stronger effect on executive compensation than other quarters, the estimated coefficients indicate that executives have little to gain by manipulating the timing of sales. For example, Oyer (1998) found that a typical firm has roughly 3\% higher sales in the fourth fiscal quarter than in the second or third. Recall that the results in Table 1 suggest that a $1 \%$ shift in sales from the second or third fiscal quarter to the fourth quarter leads to a $0.14 \%$ increase in salary and bonus. If executives' manipulation is causing all the fiscal effects discussed by Oyer (1998), then the average CEO increases his salary and bonus by about $0.42 \%$ through his choice of sales incentives. For an average CEO-year in our sample, this could lead to about a $\$ 4600$ increase in salary and bonus (or, based on regressions comparable to those in Table 1 , up to about a $\$ 20,000$ increase in "total" compensation). These percentage changes are sufficiently small that it is hard to imagine CEOs taking actions that are counter to shareholder interests, especially considering the weight of stock-based compensation for CEOs (see Hall and Liebman, 1998).

\subsection{The predictive value of fourth quarter sales: Shortsightedness or rational pay plan?}

The analysis in Section 2.1 is meant to determine if there may be incentives for an executive to manipulate the timing of sales. Our results imply that CEOs are 
graded on short-term results and that they can manipulate the timing of sales for their own benefit at the expense of the firm. However, as mentioned earlier, compensation committees generally make major decisions once a year (usually shortly after the end of the fiscal year), probably because it is difficult to meet regularly and also to give executives some time to develop and implement their plans ${ }^{11}$ Therefore, if recent sales growth (i.e., sales for less than the whole year between meetings) is a particularly good predictor of another performance measure's future success, the compensation committee may have a rational reason to examine the most recent measures of performance carefully.

Suppose that the compensation committee would ideally like to pay the CEO for both the current and future earnings that are generated under his watch. Explicit bonus contracts can be set up to compensate the executive for current earnings growth. These contracts are quite prevalent and make up the bulk of performance-based pay that comes in cash. ${ }^{12}$ But the firm cannot contract to pay current cash for future earnings. Ideally, the firm would like to use any subjective bonus money at its disposal to reward the CEO based on its best estimate of future earnings. ${ }^{13}$ This implies that compensation in year $t$ is determined by

$$
\Delta c_{i t}=a+\beta_{1} \Delta p_{i t}+\beta_{2} \Delta E_{t}\left[p_{i t+1}\right]+\Delta \varepsilon_{i t}
$$

where $p_{i t}$ is the profits or earnings of firm $i$ in year $t$.

Suppose that the firm has an unbiased estimate of $p_{i t+1}$ when it determines $c_{i t}$, such that

$$
p_{i t+1}=E_{t}\left[p_{i t+1}\right]+\psi_{i t}
$$

where $\psi_{i t}$ is a zero-mean random variable. Then we can estimate Eq. (3), using actual $p_{i t+1}$ in place of $E_{t}\left[p_{i t+1}\right] .{ }^{14}$ Though $\psi_{i t}$ causes attenuation bias in our estimate of $\beta_{2}$, we can at least get a reasonable lower bound for the effect of next year's profit on this year's compensation.

We use two different measures of profitability - log pre-tax income and return on assets (ROA). ${ }^{15}$ Log pre-tax income is problematic because it is not defined at

\footnotetext{
${ }^{11}$ Compensation committees meet more often than once per year so our treatment of the compensation determination process is a simplification. As long as the meetings early in the fiscal year are relatively important in determining bonuses and making changes in bonus plans, then our approach will pick up incentives to manipulate performance.

${ }^{12}$ See Murphy (1998) for a detailed analysis of explicit bonus plans and see Section 3 for further discussion of how CEO pay is affected by these plans.

${ }^{13}$ Explicit formulae determine the bulk of executive bonus payments (Murphy, 1999). But see Bushman et al. (1996), Ittner et al. (1997), and Hayes and Schaefer (1999) for evidence that the board retains at least some discretion when assigning bonuses to CEOs.

${ }^{14}$ Hayes and Schaefer (1999) consider the same issue from a different perspective. They regress ROA on the residual of the preceding year's executive pay. Their results and conclusions are consistent with ours.

${ }^{15}$ Unlike sales, we do not need quarterly profitability measures in this section. Therefore, the annual profit measures are based on actual annual profits rather than the sum of the four quarters' profit measures.
} 
unprofitable firms and it can reach extreme negative values for marginally profitable firms. For any unprofitable fiscal year, we set the change in log pre-tax income to zero and add dummy variables for going from profitable to unprofitable and for going from unprofitable to profitable. Despite this problem, log pre-tax income has several advantages relative to return on assets. First and foremost, the natural $\log$ is the same normalization as we use for sales, so it is easier and more consistent to compare the inter-relationship between log profit and log sales. Also, discretionary choices in dividends, write-downs, financing, and other areas affect the denominator of ROA. This leads ROA to be relatively more negatively autocorrelated than pre-tax income and makes it more difficult to examine the time-series properties of income and sales. Clearly, neither of the two measures of income is perfect so we show results using both measures.

The results in Table 2 indicate that executive pay patterns are consistent with boards compensating both current and future profitability, because $\hat{\beta}_{1}$ and $\hat{\beta}_{2}$ from Eq. (3) are both positive and significant. As seen in Table 2A, CEOs receive about a $0.28 \%$ pay increase for every $1 \%$ increase in pre-tax income. In addition, CEOs receive roughly a $0.04 \%$ (column 2 ) increase this year for every $1 \%$ increase in pre-tax income next year, though this effect is not quite statistically significant. ${ }^{16}$ Also, CEOs lose about $4 \%$ (which is statistically significant) of this year's pay if the company goes from profitable this year to unprofitable next year. The results in column 3 of Table $2 \mathrm{~B}$ indicate that CEOs receive a $1.7 \%$ pay increase this year for every increase of $1 \%$ in ROA this year and a $0.29 \%$ pay increase this year for every increase of $1 \%$ in next year's ROA.

The results in Table 2 are consistent with the board exercising at least some discretion in allocating bonuses to CEOs and with the board using projections of future profits as a factor in bonus determination. If some compensation committees do operate this way, then how do they form estimates of next year's profits when setting this year's bonus? If a board simply used this year's earnings or earnings growth to estimate next year's earnings, then $\beta_{2}$ would be zero. This suggests that the firm would like to find some accounting variable, $k_{i t}$, such that

$$
p_{i t+1}=p_{i t}+\alpha+\phi k_{i t}+\eta_{i t} .
$$

Then it could pay the CEO if he increased $k$ this period, which the firm would expect to lead to an increase in profit next period.

As shown in Table 3, sales growth appears to be a useful $k$ in that this year's sales growth has significant explanatory power for next year's profit growth. ${ }^{17}$

\footnotetext{
${ }^{16}$ Unlike Table 1, the coefficient estimates do not need to be multiplied by 4 .

${ }^{17}$ Table 3A imposes a potentially important selection condition. Because log pre-tax income is undefined for unprofitable firm-years, Table $3 \mathrm{~A}$ is limited to firms that are profitable in two consecutive years. We think of this as a measure of how relatively stable and profitable firms operate, while we assume there is another process that causes a firm to be either profitable or unprofitable. Table 3B does not have the same selection issue.
} 
Table 2

Response of CEO compensation to profits

Least squares regressions. The dependent variable is change in annual log (salary plus bonus) collected from Forbes. Pre-tax income and ROA are collected from COMPUSTAT. The sample period is 1990-1996. Banks are not included because sales is not a relevant scale measure. $t$ subscripts refer to years. q4 refers to the fourth fiscal quarter of year $t$. Each firm's last observation is dropped because future net income is not available. To remove the effect of outliers, observations are dropped if either change in income measure is greater than one. Absolute value of $t$-statistics, which are based on Huber adjustments for heteroskedasticity and within-company serial correlation, are in parentheses.

\begin{tabular}{|c|c|c|c|c|c|}
\hline & (1) & (2) & (3) & (4) & (5) \\
\hline \multicolumn{6}{|c|}{ Panel A: Pre-tax income as profitability measure } \\
\hline Change in log pre-tax income ${ }_{t}^{\mathrm{a}}$ & $0.2797 * * *(9.61)$ & & $0.2781^{* * *}(9.59)$ & $0.2660 * * *(9.22)$ & $0.2655^{* * *}(9.31)$ \\
\hline Change in log pre-tax income ${ }_{t+1}^{\mathrm{a}}$ & & $0.0346(1.41)$ & $0.0307(1.36)$ & & $0.0232(1.03)$ \\
\hline$=1$ if $\left(\text { pre-tax income } \text { in }_{t}<0\right)^{\mathrm{b}}$ & $0.1908 * * *(5.99)$ & & $0.1957 * * *(6.09)$ & $0.1897 * * *(6.00)$ & $0.1952 * * *(6.11)$ \\
\hline$=1$ if $\left(\text { pre-tax income } \text { in }_{t}<0\right)^{\mathrm{b}}$ & $-0.2017 * * *(7.86)$ & $-0.1407 * * *(6.11)$ & $-0.1895^{* * *}(7.18)$ & $-0.1958^{* * *}(7.64)$ & $-0.1849 * * *(7.06)$ \\
\hline$=1$ if $\left(\text { pre-tax income } \text { tr }_{t}<0\right)^{\mathrm{b}}$ & & $-0.0400(1.61)$ & $-0.0500^{* *}(2.20)$ & & $-0.0494^{* *}(2.17)$ \\
\hline$\left(\right.$ Change in log sales $\left.{ }_{t}\right) \mathrm{q} 4$ & & & & $0.0931^{*}(1.81)$ & $0.0847(1.64)$ \\
\hline Constant & $0.0401 * * *(7.21)$ & $0.0645^{* * *}(10.63)$ & $0.0408 * * *(7.28)$ & $0.0366^{* * *}(6.52)$ & $0.0380 * * *(6.63)$ \\
\hline$R^{2}$ & 0.1446 & 0.0317 & 0.1478 & 0.1473 & 0.1500 \\
\hline$N$ & 1769 & 1769 & 1769 & 1769 & 1769 \\
\hline \multicolumn{6}{|c|}{ Panel B: Return on assets as profitability measure } \\
\hline Change in $\mathrm{ROA}_{t}^{(\mathrm{c})}$ & $1.6551^{* * *}(7.29)$ & & $1.7247 * * *(7.92)$ & $1.5832 * * *(7.02)$ & $1.6512 * * *(7.60)$ \\
\hline Change in $\mathrm{ROA}_{t+1}^{(\mathrm{c})}$ & & $-0.1263(0.71)$ & $0.2851^{*}(1.78)$ & & $0.2756^{*}(1.75)$ \\
\hline$\left(\right.$ Change in log sales $\left.{ }_{t}\right) \mathrm{q} 4$ & & & & $0.1751^{* * *}(3.44)$ & $0.1734 * * *(3.41)$ \\
\hline Constant & $0.0502 * * *(9.63)$ & $0.0456^{* * *}(8.22)$ & $0.0510 * * *(9.93)$ & $0.0438 * * *(8.60)$ & $0.0446^{* * *}(8.84)$ \\
\hline$R^{2}$ & 0.1013 & 0.0006 & 0.1042 & 0.1110 & 0.1137 \\
\hline$N$ & 1941 & 1941 & 1941 & 1941 & 1941 \\
\hline
\end{tabular}

\footnotetext{
${ }^{a}$ Defined as the change in log annual pre-tax income.

${ }^{\mathrm{b}}$ Equals 1 if pre-tax income for the whole year is negative.

${ }^{\mathrm{c}}$ Defined as pre-tax income for the year divided by the average quarter-ending assets.

* Significant at $10 \%$ level.

** Significant at $5 \%$ level.

$* * *$ Significant at $1 \%$ level.
} 
Column 1 of Table 3A indicates that a $1 \%$ sales increase in each of year $t$ 's four fiscal quarters leads, on average, to a $0.28 \%(0.0703 \times 4)$ increase in year $t+1$ profits. But the estimates in columns $2-5$ show that sales growth in each quarter of year $t$ becomes an increasingly effective predictor of year $t+1$ profits. When looking at the effect of all quarters simultaneously (column 6), we find that, once fourth quarter sales growth is known, no other quarter's sales growth has any additional explanatory power for year $t+1$ profit growth. Finally, the results in columns 7-9 confirm that earnings growth is autocorrelated. But sales growth is better at predicting future earnings growth than current earnings growth is at predicting future earnings growth. Therefore, incentives can be improved by using sales growth to proxy for future earnings. ${ }^{18}$

The different normalization leads the ROA/sales growth relationship to be somewhat different than the pre-tax income/sales growth relationship. However, as shown in Table $3 \mathrm{~B}$, year $t$ fourth quarter sales growth is positively related to year $t+1$ ROA. But this is not true for other quarters of year $t .{ }^{19}$

One interpretation of Table 3 is that, if the compensation committee meets after the end of the fiscal year (or if it explicitly ties the bonus to sales growth), then it can use fourth quarter sales growth this year to tie compensation to next year's profits. However, except to meet other goals such as smooth sales, a firm that is trying to reward expected profits next year has no reason to attach compensation to sales growth in the first three fiscal quarters of the current year.

Tables 1-3, therefore, lead us to conclude that there may be a rational reason for the firm to ask the CEO "What have you done for me lately?' Firms may try to reward CEOs for future profit growth, which can be more accurately predicted by the previous year's fourth quarter sales growth than by sales growth in any other quarter or even past profit growth. This suggests that, at the time bonuses are determined, the compensation committee can best pay for future earnings by tying compensation to fourth fiscal quarter sales growth.

\footnotetext{
${ }^{18}$ Equity markets appear to anticipate some of the changes in pre-tax income, because we also found that year $t+1$ pre-tax income increases are related to year $t$ stock price increases. But when stock return is added to the regressions in Table 3, the effect of fourth quarter year $t$ sales growth is not changed. Since the firm typically wants to reward stock return directly and since sales growth contains information about future profits that is not contained in stock returns, sales growth is a potentially useful instrument for rewarding future profit growth.

${ }^{19}$ Note that, in the regressions of pay on performance (Table 2), the fourth quarter sales coefficient does not drop much when controlling for future profitability (column 5 of both panels). Though we might have expected a large drop in the sales coefficient if it is proxying for future profits, fourth quarter sales are clearly an imperfect measure of future profits. Also, though the coefficient on future profits drops somewhat, the fact that future profits still explain current pay when controlling for fourth quarter sales suggests that boards may be using other indicators of future profitability in addition to recent sales.
} 
Table 3

Predicting future profitability with current accounting variables

Panel A: Pre-tax income as profitability measure ${ }^{\mathrm{c}}$

(1)

(1) - (2)

(2) (3)

(4)

(5)

(6)

(7)

$(8)$

(9)

Change in lag log sales ${ }^{\mathrm{a}} \quad 0.0703 * * *$

(Change in lag log sales)q1

$$
\text { (3.34) }
$$

$$
\begin{aligned}
& 0.1508^{* *} \\
& (2.48)
\end{aligned}
$$

(Change in lag log sales)q2

(Change in lag log sales)q3

(Change in lag log sales)q4

Change in lag log pre-tax income

(Change in lag log pre-tax income) $\mathrm{q} 4$

Constant

$R^{2}$

$N^{\mathrm{b}}$

$\begin{array}{lllllllll}0.0424 * * * & 0.0487 * * * & 0.0454 * * * & 0.0431^{* * *} & 0.0416^{* * *} & 0.0419 * * * & 0.0345 * * * & 0.0364 * * * & 0.0207 * * \\ (5.67) & (7.41) & (6.60) & (6.04) & (5.77) & (5.61) & (5.08) & (5.53) & (2.56) \\ 0.0194 & 0.0071 & 0.0147 & 0.0195 & 0.0253 & 0.0270 & 0.0054 & 0.0073 & 0.0368 \\ 2379 & 2379 & 2379 & 2379 & 2379 & 2379 & 2047 & 2047 & 2047\end{array}$

$0.3190 * * *$

(3.56)

0.0144

(0.77)

$0.0460 * *$
$(2.42)$

$0.0380 * * *$

(2.63)

$0.0364 * * * 0.0207 * *$

$2047-2047$ 
Panel B: Return on assets as profitability measure ${ }^{\mathrm{d}}$

\begin{tabular}{|c|c|c|c|c|c|c|c|c|c|}
\hline & (1) & (2) & (3) & (4) & (5) & (6) & (7) & (8) & (9) \\
\hline Change in lag log sales ${ }^{\mathrm{a}}$ & $\begin{array}{l}-0.0085^{* * * *} \\
(2.76)\end{array}$ & & & & & & & & \\
\hline (Change in lag log sales)q1 & & $\begin{array}{l}-0.0299 * * * \\
(2.96)\end{array}$ & & & & $\begin{array}{l}0.0046 \\
(0.20)\end{array}$ & & & \\
\hline (Change in lag log sales)q2 & & & $\begin{array}{l}-0.0451^{* * * *} \\
(3.49)\end{array}$ & & & $\begin{array}{l}-0.0686^{* *} \\
(2.36)\end{array}$ & & & \\
\hline (Change in lag log sales)q3 & & & & $\begin{array}{l}-0.0244^{* *} \\
(1.98)\end{array}$ & & $\begin{array}{c}-0.0107 \\
(0.53)\end{array}$ & & & \\
\hline (Change in lag log sales)q4 & & & & & $\begin{array}{c}-0.0052 \\
(0.57)\end{array}$ & $\begin{array}{l}0.0407 * * * \\
(2.78)\end{array}$ & & & $\begin{array}{l}0.0084 \\
(0.95)\end{array}$ \\
\hline Change in lag ROA & & & & & & & $\begin{array}{l}-0.3288^{* * *} \\
(7.15)\end{array}$ & & $\begin{array}{l}-0.3317^{* * *} \\
(7.28)\end{array}$ \\
\hline (Change in lag ROA)q4 & & & & & & & & $\begin{array}{l}-0.3312^{* * *} \\
(4.03)\end{array}$ & \\
\hline Constant & $\begin{array}{l}0.0032^{* *} \\
(3.08)\end{array}$ & $\begin{array}{l}0.0030^{* * *} \\
(2.90)\end{array}$ & $\begin{array}{l}0.0033^{* * *} \\
(3.21)\end{array}$ & $\begin{array}{l}0.0030 \text { *** } \\
(2.84)\end{array}$ & $\begin{array}{l}0.0026^{* *} \\
(2.55)\end{array}$ & $\begin{array}{l}0.0029 * * * \\
(2.89)\end{array}$ & $\begin{array}{l}0.0017^{* * *} \\
(1.40)\end{array}$ & $\begin{array}{l}0.0025^{* *} \\
(2.26)\end{array}$ & $\begin{array}{l}0.0015 \\
(1.28)\end{array}$ \\
\hline$R^{2}$ & 0.0063 & 0.0059 & 0.0138 & 0.0048 & 0.0002 & 0.0205 & 0.1070 & 0.0279 & 0.1076 \\
\hline$N$ & 1720 & 1720 & 1720 & 1720 & 1720 & 1720 & 1720 & 1720 & 1720 \\
\hline
\end{tabular}

${ }^{a}$ Defined as the sum of the four quarters' change in log sales.

${ }^{\mathrm{b}}$ Sample size changes because observations with negative net income in the previous year or previous fourth quarter are eliminated.

${ }^{c}$ Least squares regressions. The dependent variable is change in annual log (pre-tax income) collected from COMPUSTAT. The sample period is $1990-1996$. Unprofitable year $t$ and $t-1$ observations are excluded from all columns. Also, to exclude outliers, observations for which the absolute value of the dependent variable is greater than one are dropped. Banks are not included. Absolute value of $t$-statistics, which are based on Huber adjustments for heteroskedasticity and within-company serial correlation, are in parentheses.

${ }^{\mathrm{d}}$ Least squares regressions. The dependent variable is change in annual ROA. Banks are not included. Absolute value of $t$-statistics, which are based on Huber adjustments for heteroskedasticity and within-company serial correlation, are in parentheses.

* Significant at $10 \%$ level.

** Significant at $5 \%$ level.

$* * *$ Significant at $1 \%$ level. 


\section{The effect of the timing of profits on executive compensation}

\subsection{Background}

According to Healy (1985), a common form of executive bonus plan is to pay a linear piece rate for fiscal year profits above some pre-determined lower bound. Many plans also include a cap on bonus payments. The profit measure varies across firms, with most firms using measures of pre-tax income (see Healy, 1985; Gaver et al., 1995 — hereafter referred to as GGA). The size of cash bonus pools, and their importance relative to stock options, also varies significantly by firm. See, for example, Murphy (1998).

Executives have some level of discretion over their firms' accounting accruals and other accounting procedures. Healy found evidence that managers manipulate accounting accruals in such a way as to exploit the non-linearities in bonus schemes and maximize their bonuses. He found that managers whose firms are above or below the bounds of the bonus program choose income-decreasing strategies (sometimes referred to as "taking a bath") that defer firm income to a time when it has more impact on their personal compensation. Managers whose firms are within the bounds of the bonus program, however, choose income-increasing strategies.

Holthausen et al. (1995) and GGA, using different data than Healy, find that Healy overestimated the amount of income reduction driven by executives. These studies confirm, however, that income-increasing strategies are widely used as a means to increase bonus pool payouts. ${ }^{20}$ They say that Healy's use of total accruals, instead of discretionary accruals, biased his results. Because they found no evidence of income-decreasing activity below bonus lower bounds, and because many plans do not include an upper bound (less than one third of Healy's sample had one), the studies suggest that income-increasing is much more prevalent than income-decreasing. Both of these studies, as well as Degeorge et al. (1999), also found that CEOs, in addition to maximizing their bonuses, may be trying to smooth their firms' profits from one year to the next.

These previous studies have used data from firms that have executive bonus plans and explicitly state their terms in proxy statements. Only $38 \%$ of the sample by Healy (1985), and $8 \%$ of GGA, met these criteria, making it unclear how applicable their findings are to most firms. Our methodology is a much less direct test of bonus plan manipulation. However, by looking at a broader set of companies, we hope to determine if income-increasing and/or income-decreasing

\footnotetext{
${ }^{20}$ Weisbach (1988) provides further evidence consistent with income-increasing activities. A CEO whose compensation is based on firm income has particularly strong incentives to increase income if he knows it is his last year, because he gains nothing from income in future years. Weisbach found that firm income is relatively high in a year preceding an anticipated CEO retirement.
} 
activity are widespread and we can measure whether this activity significantly affects CEOs' total pay packages.

If income increasing and/or income decreasing activity are undertaken strictly to maximize executive bonus payments, and the manipulation typically takes place in the fourth quarter, then we would expect to find that fourth quarter profits are more important in determining executive compensation than profits from other quarters. That is, when estimating Eq. (2) and using profitability as the explanatory variable, we would expect to find that $\delta_{4}>\delta_{1}, \delta_{2}, \delta_{3}$. However, if income manipulation does take place, but the primary goal of the executives undertaking the manipulation is to smooth the firm's earnings, then we would expect to find that fourth quarter earnings (and, if the manipulation is undone in the following first fiscal quarter, first quarter earnings) are less important in determining executive compensation (i.e., $\delta_{4}, \delta_{1}<\delta_{2}, \delta_{3}$ ). Finally, if income manipulation is not common or if it has small effects on the overall compensation of CEOs, then we should find that quarterly earnings have a fairly uniform effect on pay. ${ }^{21}$

\subsection{Empirical measurement of bonus plan manipulation}

As in Section 2, we use pre-tax income and ROA as our profit measures. Pre-tax income is the most common profit measure in plans described by Healy (1985) and GGA. We obtained similar results when using net income as the explanatory variable. ${ }^{22}$ The problem of log income being sometimes undefined is exacerbated because, in this section, we use the sum of the four quarters change in $\log$ income as our measure of annual change in log income. If any quarter has negative pre-tax income, we are unable to measure the change in log income for the whole year. While $8 \%$ of firm years have negative pre-tax income, our methodology (the annual measure is equal to the sum of the four quarterly measures) leads us to treat $22 \%$ of firm years as having negative pre-tax income in regressions when we include the annual compensation measure.

The first two columns of Table 4 display our results when estimating a least squares regression of the change in the log of salary plus bonus on the change in the log of pre-tax income. Column 1 indicates that a $1 \%$ increase in annual pre-tax income leads to about a $0.22 \%$ change in executive pay. ${ }^{23}$ If a firm goes from

\footnotetext{
${ }^{21}$ These expected patterns are based on simulations we performed (but do not report in the tables). Due to the introduction of an errors-in-variables problem, the fourth (and possibly first) quarter would have lower coefficients if managers attempt to smooth firm income.

${ }^{22}$ Though the bonus payouts are often made in the following year, corporations use "accrual accounting" methods and their proxy statements report compensation in the year it was earned, not the year it is paid. So we regress the measures of compensation on current year quarterly performance.

${ }^{23}$ Again we have multiplied the coefficient by 4 when examining increases in income over a whole year. If we use the change in log profit for the year, instead of using the sum of change in quarterly profits, we find that a $1 \%$ increase in firm pre-tax income leads to a $0.109 \%$ increase in CEO salary and bonus, with a $t$-statistic of 9.5 . This is somewhat smaller than the coefficient implied by Table 4 , but leads to the same general conclusions.
} 
Table 4

Response of CEO compensation to profit timing

Least squares regressions. The dependent variable is change in log (salary plus bonus) collected from Forbes. All other data are collected from COMPUSTAT. The sample period is 1990-1996. Absolute value of $t$-statistics, which are based on Huber adjustments for heteroskedasticity and within-company serial correlation, are in parentheses.

\begin{tabular}{|c|c|c|c|c|}
\hline & (1) & (2) & (3) & (4) \\
\hline Change in $\log \mathrm{PTI}^{\mathrm{a}}$ & $\begin{array}{l}0.0541^{* * *} \\
(9.78)\end{array}$ & & & \\
\hline (Change in $\log \mathrm{PTI}) \mathrm{q} 1$ & & $\begin{array}{l}0.0451^{* * * *} \\
(4.42)\end{array}$ & & \\
\hline (Change in log PTI)q2 & & $\begin{array}{l}0.0607^{* * *} \\
(6.25)\end{array}$ & & \\
\hline (Change in $\log \mathrm{PTI}) \mathrm{q} 3$ & & $\begin{array}{l}0.0586^{* * * *} \\
(5.27)\end{array}$ & & \\
\hline (Change in log PTI)q4 & & $\begin{array}{l}0.0446^{* * * *} \\
(4.58)\end{array}$ & & \\
\hline $1 *(\log \mathrm{PTI}<0)^{\mathrm{b}}$ & $\begin{array}{l}-0.1700^{* * *} \\
(10.75)\end{array}$ & by quarter & & \\
\hline $1 *(\operatorname{lag} \log \mathrm{PTI}<0)^{\mathrm{b}}$ & $\begin{array}{l}0.1391^{* * *} \\
(8.83)\end{array}$ & by quarter & & \\
\hline Change in $\mathrm{ROA}^{\mathrm{c}}$ & & & $\begin{array}{l}1.7298^{* * *} \\
(7.88)\end{array}$ & \\
\hline (Change in ROA)q1 & & & & $\begin{array}{l}2.0431^{* * *} \\
(3.75)\end{array}$ \\
\hline (Change in ROA)q2 & & & & $\begin{array}{l}1.9573^{* * *} \\
(4.64)\end{array}$ \\
\hline (Change in ROA)q3 & & & & $\begin{array}{l}1.2474^{* *} \\
(1.98)\end{array}$ \\
\hline (Change in ROA)q4 & & & & $\begin{array}{l}1.9037^{* * *} \\
(5.86)\end{array}$ \\
\hline Constant & $\begin{array}{l}0.0421^{* * * *} \\
(8.80)\end{array}$ & $\begin{array}{l}0.0391^{* * *} \\
(8.89)\end{array}$ & $\begin{array}{l}0.0573^{* * *} \\
(12.89)\end{array}$ & $\begin{array}{l}0.0573^{* * *} \\
(12.88)\end{array}$ \\
\hline$R^{2}$ & 0.1224 & 0.1631 & 0.0944 & 0.0983 \\
\hline$P$-value on restrictions ${ }^{\mathrm{d}}$ & & 0.608 & & 0.819 \\
\hline$N^{\mathrm{e}}$ & 3090 & 3090 & 2369 & 2369 \\
\hline
\end{tabular}

'Defined as the sum of the four quarters' change in log pre-tax income.

${ }^{\mathrm{b}}$ In column 1, this variable equals 1 if any of the four quarters in current or lag year have negative net income.

${ }^{\mathrm{c}}$ Defined as the sum of the four quarters' ROA.

${ }^{\mathrm{d}} P$-value is from an $F$-test of the null hypothesis that the effect of the profitability measure is the same across fiscal quarters.

${ }^{\mathrm{e}}$ Sample size changes because quarterly assets were not always available.

* Significant at $10 \%$ level.

** Significant at $5 \%$ level.

$* * *$ Significant at $1 \%$ level.

profitability to non-profitability, the CEO can expect about a $17 \%$ pay cut. When a firm becomes profitable after a year of losses, the CEO can expect about a $14 \%$ 
pay increase. However, column 2 illustrates that there is not a statistically significant difference between the quarterly effects on compensation. Columns 3 and 4 show similar results using ROA as the profitability measure. We see no evidence that the profit increasing strategies caused by bonus plans has any significant effect on how individual fiscal-quarter profits determine executive compensation.

There are at least three possible reasons we do not find that the effect of profitability on executive compensation differs by quarter. First, income smoothing could be a goal of CEOs, but, because they also attempt to maximize their compensation, the effect is not strong enough to prove significant. Second, it could be the case that the bonuses discussed by Healy (1985) are not a substantial enough portion of executive compensation, or at least the portion that can be manipulated through accruals is not large enough, to show up as a dominant factor in executive pay. Finally, it is possible that long-term compensation and stock options dominate executive bonus plans, so the main effects of fourth quarter manipulation cannot be identified when looking at salary and bonus alone.

\section{Concluding comments}

We have investigated the incentives of executives to manipulate the timing of their firms' performance by measuring how CEO pay-for-performance varies over the fiscal year. While we might have expected that compensation committees would want to reward performance consistently throughout the year, we found evidence that they are not completely successful in attaining this goal. We found that even though we know of no explicit evidence that managerial pay is based on quarterly results, the opportunity does exist for CEOs to increase their expected compensation by shifting their firms' sales between periods. However, this effect is relatively small and may be a rational response to the most up-to-date information that relates to CEO performance. We also found no evidence that the average CEO can gain by manipulating the timing of profits. Our general conclusion is that CEOs can "game" their compensation plans to maximize their pay, but that the returns to this gaming, while not trivial in absolute terms, do not make up a major portion of CEO pay. Our results are consistent with boards of directors using recent sales growth as a proxy for future profitability when assigning discretionary bonuses, while rewarding accounting profits almost exclusively through explicit bonus contracts.

Understanding the roots of our results requires thorough study of the workings of compensation committees. Do compensation committees consider the possibility of executives "gaming" their compensation, but just accept that this is a cost of putting an "agent" in charge of the company's operations? It would be enlightening to look within individual firms at the timing of management contract decisions and how managers react to them. Also, firm level data that matches 
individual accounting accrual decisions (rather than annual accruals, as in Healy, 1985, and GGA) with the compensation contracts of managers has the potential to more accurately measure the importance of bonus plan manipulation.

\section{Acknowledgements}

We thank David Card, Henry Farber and Scott Schaefer for suggestions, Kevin J. Murphy for many helpful comments, and participants in the Princeton Labor Lunch, Harvard Business School/MIT Sloan School Economics of Organizations Seminar, the Kellogg School Accounting Seminar, and the 1997 Winter Meetings of the Econometric Society in New Orleans. Oyer received generous support from an Alfred P. Sloan Foundation Doctoral Dissertation Fellowship. This is a substantially revised version of a paper originally circulated under the title "What Have You Done for Me Lately?: Executive Compensation and the Timing of Corporate Performance."

\section{Appendix A. Summary statistics}

This table provides summary statistics of the executive compensation (from Forbes Magazine), firm accounting (from COMPUSTAT), and stock market return data (from CRSP). Sample is firms with relevant data available for two or more consecutive years, 1990-1996. Compensation is in \$000. Firm accounting figures are in \$million. All dollar figures are in \$1990, deflated by the Consumer Price Index. Banks and bank holding companies are excluded from sales and operating profit calculations. Standard errors are in parentheses.

\begin{tabular}{|c|c|c|c|c|c|c|}
\hline & Annual & Quarter 1 & Quarter 2 & Quarter 3 & Quarter 4 & $N$ \\
\hline Sales & $\begin{array}{l}5269.1 \\
(173.3)\end{array}$ & $\begin{array}{l}1260.2 \\
(41.4)\end{array}$ & $\begin{array}{l}1303.5 \\
(43.3)\end{array}$ & $\begin{array}{l}1306.5 \\
(41.9)\end{array}$ & $\begin{array}{l}1398.9 \\
(47.3)\end{array}$ & 2590 \\
\hline Pre-tax income & $\begin{array}{l}403.5 \\
(14.2)\end{array}$ & $\begin{array}{l}102.8 \\
(3.7)\end{array}$ & $\begin{array}{l}108.7 \\
(3.8)\end{array}$ & $\begin{array}{l}104.6 \\
(3.7)\end{array}$ & $\begin{array}{l}87.5 \\
(4.5)\end{array}$ & 3090 \\
\hline ROA (\%) & $\begin{array}{l}7.6 \\
(0.2)\end{array}$ & $\begin{array}{l}1.8 \\
(0.05)\end{array}$ & $\begin{array}{l}2.0 \\
(0.05)\end{array}$ & $\begin{array}{l}2.0 \\
(0.06)\end{array}$ & $\begin{array}{l}1.8 \\
(0.06)\end{array}$ & 2369 \\
\hline Salary, bonus & $\begin{array}{l}1097 \\
(17.4)\end{array}$ & - & - & - & - & 2590 \\
\hline Salary, bonus, other & $\begin{array}{l}1440 \\
(27.3)\end{array}$ & - & - & - & - & 2590 \\
\hline Total compensation & $\begin{array}{l}2274 \\
(106.2)\end{array}$ & - & - & - & - & 2590 \\
\hline
\end{tabular}

\section{References}

Bushman, R.M., Indjejikian, R.J., Smith, A., 1996. CEO compensation: the role of individual performance evaluation. Journal of Accounting and Economics 21, 161-193. 
Camerer, C., Babcock, L., Loewenstein, G., Thaler, R., 1997. Labor supply of New York City cabdrivers: One day at a time. The Quarterly Journal of Economics 112, 407-441.

Chevalier, J., Ellison, G., 1997. Risk taking by mutual fund managers as a response to incentives. Journal of Political Economy 105, 1167-1200.

Degeorge, F., Patel, J., Zeckhauser, R., 1999. Earnings management to exceed thresholds. Journal of Business 72, 1-39.

Gaver, J.J., Gaver, K.M., Austin, J.R., 1995. Additional evidence on bonus plans and income management. Journal of Accounting and Economics 19, 3-28.

Hall, B.J., Liebman, J.B., 1998. Are CEOs really paid like bureaucrats? The Quarterly Journal of Economics 113, 653-691.

Hayes, R.M., Schaefer, S., 1999. Implicit contracts and the explanatory power of top executive compensation for future performance. J.L. Kellogg Graduate School of Management, Northwestern University, Evanston, IL.

Healy, P.M., 1985. The effect of bonus schemes on accounting decisions. Journal of Accounting and Economics 7, 85-107.

Holthausen, R.W., Larker, D.F., Sloan, R.G., 1995. Annual bonus schemes and the manipulation of earnings. Journal of Accounting and Economics 19, 29-74.

Ittner, C.D., Larcker, D.F., Rajan, M.V., 1997. The choice of performance measures in annual bonus contracts. Accounting Review 72, 231-255.

Jensen, M.C., Murphy, K.J., 1990. Performance pay and top-management incentives. Journal of Political Economy 98, 225-264.

Kim, S.K., 1997. Limited liability and bonus contracts. Journal of Economics and Management Strategy 6, 899-913.

Leventis, A., 1997. Cardiac surgeons under scrutiny: A patient-selection hypothesis. Princeton University, Princeton, NJ.

Murphy, K.J., 1985. Corporate performance and managerial remuneration: An empirical analysis. Journal of Accounting and Economics 7, 59-76.

Murphy, K.J., 1998. Performance standards in incentive contracts. Working paper, University of Southern California, Los Angeles.

Murphy, K.J., 1999. Executive compensation. In: Ashenfelter, O., Card, D. (Eds.), Handbook of Labor Economics, Vol. 3, North-Holland, Amsterdam.

Oyer, P., 1998. Fiscal year ends and non-linear incentive contracts: The effect on business seasonality. The Quarterly Journal of Economics 113, 149-185.

Weisbach, M.S., 1988. Outside directors and CEO turnover. Journal of Financial Economics 20, 431-460. 